\title{
ÚTMUTATÓ SZTEREOTÍPIÁINK ÉRTELMEZÉSÉHEZ
}

\section{CSEREKLYE ERZSÉBET}

\author{
az Eötvös Loránd Tudományegyetem Pedagógiai és Pszichológiai Kar \\ Neveléstudományi Doktori Iskolájának doktorandusz hallgatója \\ ecsereklye@t-online.hu
}

José Eugenio Abajo Alcade Cigány gyerekek az iskolában címü könyve egy évtizedes kutatói munka tapasztalatait, eredményeit mutatja be, egy kis spanyol város közösségében vizsgálva a rasszizmus különböző formáinak kialakulását és legitimációs folyamatait, az interkulturális kapcsolatok dinamikáját és a társadalmi egyenlötlenségeket fenntartó rendszer múködését. A kutatás eredményeként, a rejtett vagy nyílt rasszizmust alátámasztó, nagyszámú tudományos és általános sztereotípia részletes elemzésével a szerző univerzálisan értelmezhető gyakorlati magyarázatokat fogalmaz meg a csoportok közti kapcsolatok minőségének alakulására. A szerző átfogóan mutatja be a cigányokhoz, társadalmi beilleszkedésük kudarcaihoz kötődő sztereotípiákat, felületes értelmezési modelleket.

A könyv két fő részből áll: az elsőben megismerhetjük a kutatás módszertanát és elméleti hátterét, a második rész pedig a kutatás eredményeit ismerteti, nagyon részletesen és érzékletesen bemutatva a cigányok méltányos társadalmi szerepvállalását gátló struktúrákat és gondolkodást. A kutatás elméleti hátterének bemutatásánál felhívja a figyelmet azokra, a közbeszédben gyakran széleskörben elfogadottnak tekintett egysíkú értelmezésekre, amelyek a cigányok jelenlegi társadalmi helyzetére próbálnak determinista magyarázatot adni. Ilyen magyarázat az etnikum és a család hibáztatása, amikor a helyzetükért egyértelműen az egyes cigány családokat vagy általában a cigány kisebbséget teszik felelössé, tagjaikat alkalmatlanoknak és felkészületleneknek tartják, mert „,nem törődnek semmivel”, „önmagukat rekesztik ki”, vagy épp azért, mert ,,a cigány szülők nem törődnek a gyermekek iskoláztatásával" (32-33. o.). Egy másik, egysíkú megközelítés az ún. pszichologizáló magatartás, amely a cigány gyerekeket teszi felelőssé saját helyzetükért, a problémáikat egyéni problémáknak, velük született tulajdonságaik következményeinek tartja. Olyan jellemzőket tulajdonítanak nekik, mint az alacsony intellektuális szint, gyenge motiváció, fejletlen készségek, képtelenség az alkalmazkodásra, agresszivitás, kiegyensúlyozatlanság. Hasonlóan egyoldalúan próbálja értelmezni a cigány gyerekek iskolai nehézségeinek okait a szociológiai determinizmus, amely az 1970-es, 1980-as években népszerüvé vált elmélet a társadalmi struktúra reprodukcióját magyarázandó. Az elmélet szerint a többségi, felső- és középosztálybeli gyerekek olyan előnyökkel indulnak az oktatásban jobb anyagi helyzetük, a szülők iskolázottsága 
és egyéb környezeti tényezők terén, amelyek az alsóbb osztályokhoz és kisebbségekhez tartozó gyerekek számára behozhatatlanok; az oktatási reformok a rendszer szelektáló és önmagát újrateremtő müködését nem tudják megváltoztatni, mivel azok nem a diszkriminatív társadalmi szerkezetet veszik célba. A negyedik egysíkú értelmezés az oktatásban jelentkező hátrányok nyelvi hiányosságokkal való megokolása. E szerint a kisebbségek nyelvi környezetét korlátozott nyelvi kódrendszer jellemzi, mely nem tesz lehetővé jó iskolai teljesítményt. A szerző említi azt az elméletet is, amely az iskolát azonosítja a probléma forrásaként, azaz a sikertelenség okának azt tartja, hogy az iskola képtelen alkalmazkodni a kisebbségi gyerekekhez, szerkezete és hagyományai miatt nem tudja befogadni a kisebbségi gyerekek kultúráját, képtelen demokratikus módon közelíteni az interkulturális nevelés kialakításához. Ezt súlyosbíthatja a megfelelő eszközök és források hiánya is. Az utolsó, a szerző által említett egysíkú értelmezési modell az esszencialista hozzáállás, amely szerint a különböző kultúrák összeférhetetlenek, köztük állandó konfliktus van, amelynek egyetlen lehetséges megoldása a szegregáció, mindkét oldalról. Az elmélet sajátsága, hogy a deszegregált iskolai környezetben tanuló cigány gyerekeket úgy mutatja be, mint akik az iskolai és családi kultúra között örlődnek; a cigány diákok iskolai kudarcait az asszimilációval szembeni védekezésként értelmezi. Az elméleteket természetesen gyakran kombinálják, s érdekesség, hogy például a konzervatív elméletekre jellemző az etnikum és a család hibáztatása, pszichologizáló magatartással párosítva; az ún. kompenzáló megközelítés legszívesebben az etnikum hibáztatását kapcsolja össze a szociológiai determinizmussal és a nyelvi hiányosságok okolásával; a radikális elméletekre pedig leggyakrabban a szociológiai determinizmus, az iskola problémaforrásként való érzékelése és a kultúrák közti inkompatibilitás hangsúlyozása jellemző.

A szerző szerint a bemutatott értelmezésekben közös az, hogy mindegyik merev, fatalista és kauzalista, bár tagadhatatlan, hogy minden elmélet okként megjelenített változói valóban befolyásolják a cigány gyerekek iskolai sikerességét, de nem meghatározó módon.

A szerző a probléma megoldásához három kiindulópontot jelöl meg:

1. a tanulás elsősorban aktív, interperszonális folyamat, amelynek résztvevői a diák, a tanár és a diák kortársai.

2. A marginalizáció, mint társadalmi jelenség vizsgálata: a társadalmi marginalizáció jelenségét a szerző szerint az állandó társadalmi versenyhelyzet teremti meg, a sztereotípiák pedig legitimizálják. A marginalizáció létrejötte egyformán függ a szociokulturális rendszertől és a marginalizálódó csoport tulajdonságaitól, mivel bizonyos csoportok, adott pillanatban hajlamosabbak a társadalmi kirekesztődésre, mint mások.

3. A kommunikáció jelentösége a tanulás fejlödésében és a kettös kötődés elmélete Bateson nyomán: itt a szerző azt elemzi, hogy a torz vagy ellentmondásos kommunikáció milyen bizonytalanságot eredményez a gyerekekben. 
A szerző kutatásában vizsgálta a versenyhelyzet szerepét a cigány gyerekek iskolai sikertelenségében, a sztereotípiák hatását a cigány gyerekek marginalizációjára, a szegregált környezet és az iskolai kudarc összefüggéseit, illetve mindezek egymással való viszonyát.

A kutatás eredményeként rengeteg adattal alátámasztva mutatja be azt a társadalmi és iskolai környezetet, amelyben létrejött a cigány gyerekek nagyfokú kirekesztettsége. Elemzi a közoktatási intézményekbe beiratkozott gyerekek számát, területi és iskolatípusonkénti eloszlását; a szülők, tanárok és a helyi közösségek reakcióit az egyes deszegregációt segítő reformkísérletekre, mint például az iskolai étkeztetés lehetőségének megteremtése; az oktatási intézmények strukturális és attitủdbeli változásait a köztük kialakult versenyben; de megvizsgálja a város lakónegyedeiben kialakult etnikai struktúrákat és a munkához jutás esélyeit is a versenyorientált környezetben. A sztereotípiákat a marginalizáció egyik legfőbb ösztönzö és legitimáló eszközeként azonosítja a szerző. Számtalan, a kutatás során készített interjúkból származó idézet elemzése alapján azonosítja a cigányokkal kapcsolatos sztereotípiák fő típusait, melyek szerint a cigányok problémásak, abnormálisak, marginalizáltak; elemzi ezeknek a sztereotípiáknak a hatásmechanizmusát mind a többségi csoportokban (legitimált kirekesztő magatartás), mind pedig a kisebbség esetében (internalizált elnyomás, felháborodás) és a két csoport kapcsolatában is. Találó példákon keresztül mutatja be a szelektív emlékezet/szelektív feledés a sztereotípiák erősödését szolgáló mechanizmusát. A szelektív emlékezet/feledés jelensége az, amikor a sztereotípiáknak ellentmondó információk gyorsan feledésbe merülnek, a sztereotípiákat erősítő információk pedig mélyen bevésődnek az emberek emlékezetébe. A jelenség olyannyira tipikus és erős, hogy a kisebbségi sztereotípiáknak következetesen nem megfelelő kisebbségieket gyakran nem az etnikumhoz tartozóként könyvelik el. Például az iskolában sikeres cigány diákok identitását megkérdőjelezik társaik, „nem is vagy cigány”, „te csak félig vagy cigány” (111. o.)

A szerző vizsgálja a sztereotípiák „hatékonyságát” a cigányság, mint csoport marginalizáltságát igazoló és fenntartó eszközökként, a társadalom általános struktúráiban és különösen az oktatásban. A kutatás során készített interjúk tartalmának elemzésével hét fö csoportot hoz létre:

1. Az általános társadalmi jelenlétböl származó sztereotípiák: bünözők (tolvajok, ingyenélők, erőszakosak stb.); érzéketlen nyomorultak (piszkosak, primitívek, képtelenek alkalmazkodni, lusták); életmüvészek (bohémok, egzotikusak, dáridózók).

2. Kognitív sztereotípiák: a szocializáció folyamata elöítéletekkel teli környezetben zajlik, ezért a valóságról alkotott képet befolyásolja az egyén társadalmi-gazdasági környezete. Így sok sztereotípia a priori tudásnak tünhet, valóságtartalmuk csak ritkán kérdőjeleződik meg az egyénben. Ilyen tanulási folyamat eredményeként rögződnek például a cigányokhoz kötődő nyelvi fordulatok is: „piszkosabb vagy egy cigánynál”, „cigányszagod 
van”, „ha nem eszed meg, elviszik a cigányok” (117. o.), de ilyeneket tartalmaznak gyakran a viccek vagy a gyanakvó megjegyzések is.

3. A verseny okozta kirekesztést igazoló sztereotípiák: a fennálló társadalmi struktúra, a munkához való hozzáférés rendjének megőrzését szolgáló sztereotípiák, amelyek ellenséget, alacsonyabb rendü, kevesebb joggal rendelkező csoportokat igyekeznek azonosítani: „saját magukat rekesztik ki” (117. o.).

4. Történelmi gyökerü sztereotípiák: a hosszú ideig (Spanyolországban mintegy 500 évig) tartó erős diszkrimináció következtében a cigány kisebbség kultúrája sokszor a többségi kultúra szabályait semmibe vette, a legitimált viselkedésformákat a többség kultúrája bünözői viselkedésként azonosított. A korábbi sztereotípiákat (piszkos, tyúktolvaj, gyerekrabló) a korszellemnek megfelelő újabbak váltják fel (kábítószerfüggő és -fogyasztó, AIDS-es, tolvaj).

5. A társadalmi helyzettel kapcsolatos, érzelmekre építő sztereotípiák:

- csoportkohézió: a csoportok közti kapcsolatokat tiltó szófordulatok: „Nézd, ez cigányokkal barátkozik...”, ,,saját magadat se tiszteled”, ,ez, aki most ment le a lépcsőn, ez is cigány, nem?" (119. o.)

- a társadalmi pozíció védelme: leginkább a többségi csoport alsóbb társadalmi rétegeire jellemző beszédmód, akik igyekeznek elkülönülni a cigányoktól, ezért alsóbbrendủnek bélyegzik őket: fertőzőnek tartják az életmódjukat és szokásaikat, ezért igyekeznek térben is minél inkább elkülönülni tőlük, akár a lakókörnyezetről, akár az iskoláról van szó.

- a félelem sztereotípiája: az előzőhöz nagyon hasonló, de itt nem pozícióféltésről, hanem az egyéb sztereotípiák miatt mélyen beágyazódott tulajdonságok keltette félelemérzetről van szó: például egy idős cigányasszony távozása után rovarírtót szórtak szét egy boltban, „tudom, hogy nincs ez rendjén, de nem kedvelem őket”, „Már önmagukban is félelmetesek". (121. o.)

6) az érzelmekhez és a gazdasági helyzethez kapcsolódó sztereotípiák: a különbözőség, másság azonosítása a társadalmi versenyhelyzetben átélt kudarcok okaként, bünbakkeresés. (A cigányok rontják egy üzlet respektjét, tönkreteszik a felhasználói bizalmat.)

7) A félelmeink teremtette "cigány": a saját félelmek kivetítése más társadalmi csoportokra, amely az individuum és a saját csoport elfogadásának hiányára vezethető vissza. Az ennek következtében kialakuló feltételezések szerint a más, alacsonyabb rendűnek tartott csoportokkal, azok tagjaival kialakított kapcsolatban csak veszteni lehet, így igyekeznek azokat elszemélyteleníteni, elutasítani. 
A sztereotípiák elemzése során a szerző arra a következtetésre jut, hogy a többségi népcsoport alig ismeri a cigányokat, a többség körében elterjedt sztereotípiák pedig a cigányoknak szinte automatikusan és kizárólag hibákat tulajdonítanak. Az elutasítás arányainak vizsgálatakor kiderült, hogy az emberek legkevésbé a családjukba fogadnának be cigányt (36,6\%), munkatársként és kevesebb személyes kötődést igénylő helyzetekben már ennél kisebb az ellenállás. A népesség attitűdjeit vizsgáló kérdések eredménye szerint a népesség 10\%-a tartja magát rasszistának, míg további egyharmada megértően viszonyul a rasszizmushoz. „Nem vagyok raszszista, de nem szeretnék együtt élni velük”, “elszívják előlünk a levegőt.” (134. o.)

A szerző részletesen elemzi a cigányokkal kapcsolatos sztereotípiák tartalmi jellemzőit a középiskolások körében is. Elsőként a nem cigány szülők attitüdjeit vizsgálja a cigány gyerekek felé. A szülők megkülönböztetnek elfogadott és nem kívánatos osztálytársakat. A nem cigány szülők sztereotípiái szerint a cigány gyerekek neveletlenek, kevesebbet tudnak, és nem tanulnak, rossz szokásaik vannak és rosszul viselkednek, piszkosak, eröszakosak, kárt tesznek a többi gyerekben, és rontják az iskola imázsát. A szülők ugyanígy elfogadott és nem kívánatos kategóriákba osztják az iskolákat. Spanyolországban ez a fizetős, egyházi és magániskolák és az állami, cigányokat is oktató iskolák két csoportját jelenti. A megkülönböztetés kategóriái pedig a tanulók anyagi háttere, az oktatás színvonala, az iskolák tanulói „emberanyaga”, a szolgáltatások színvonala és a tanárok kvalitásai szerintiek. A szerző azonosít néhány szülői magatartásformát is, mint a bezárkózás (önkéntes szegregáció), menekülés (white fly), kapcsolatok hiánya (az iskolába járó különböző csoportokhoz tartozó gyerekek kapcsolatának nem kívánatossá nyilvánítása). A tanárok, iskolaigazgatók és iskolafenntartók attitüdjeit vizsgálva hasonlóságok fedezhetőek fel a jó és kevésbé jó iskolák megkülönböztetésében, illetve abban a félelemben, hogy a cigány diákok befogadása rontja az iskola megítélését. A szerző az interjúk elemzésével kimutatja, hogy a tanárok viselkedése, gyerekekkel való bánásmódja alapvetően meghatározza a cigány gyerekek iskolai teljesítményét, és az alacsony vagy nem létező elvárások bénítóan hatnak rájuk. A tanárokban általánosan élő sztereotíp kép szerint a cigányok rossz tanulók és rossz magaviseletűek: ,a cigányokat nem érdekli az írás, olvasás, csak az evés és a segélyek”, ,a szüleik nem foglalkoznak velük” „a cigányok sose fegyelmezettek” (167-168. o.). Az iskolák igyekeznek távol tartani a cigány gyerekeket, ezért beiratkozáskor, általában helyhiányra hivatkozva utasítják el a szüleiket, a deszegregált iskolákban tanító tanárok pedig az oktatás színvonalára hivatkozva érvelnek szegregált osztályok létrehozása mellett. Ennek hátrányait a következő kategóriákba csoportosítja a szerző:

a) a szegregált oktatás a diákra hárítja a felelősséget az iskolai kudarcért, a tanár felelőssége nem kerül szóba;

b) a szegregáció passzív, homogenizáló pedagógiát segít elö; 
c) a szegregáció eredményeként létrejövő osztályok nagyon heterogének, gyakran nagyon eltérő korú és szükségletü gyerekek tanulnak együtt a valójában etnikai alapon létrejött csoportokban;

d) a szegregált iskolai környezet megnehezíti, gyakran lehetetlenné is teszi a későbbi társadalmi beilleszkedést, állandósítja a marginalizációt.

Jellemző továbbá a cigány gyerekekkel dolgozó tanárokra, hogy a gyerekekhez nem egyforma elvárásokkal viszonyulnak, nem egyenlően ítélik meg tetteiket. A cigány gyerekek sikereit gyakran figyelmen kívül hagyják, nem kapnak dicséretet, míg hibáikat sokkal komolyabban büntetik, mint a többséghez tartozókét; hiányzásaikkal nem törődnek. Gyakran ismételtetnek velük évet, ami szintén növeli az iskolai kudarcok esélyeit.

Természetesen ellenpéldát is bemutat a szerző az olyan tanárokra utalva, akik igyekeznek megteremteni a méltányos oktatás feltételeit, támogatják és ösztönzik a gyerekeket, és megerősítik sikerélményeiket, önbecsülésüket. A cigány gyerekek és osztálytársaik viszonyát vizsgálva a kortársakban élő sztereotípiák forrásait elemzi. Ezek elsősorban a szülőktől származnak, de más csatornákon keresztül is eljutnak a gyerekekhez, mint például a média, az osztálytársakkal folytatott beszélgetések vagy épp a tanárok viselkedése. Azonban a vizsgált spanyol iskolákban gyakorlatilag cigány és nem cigány gyerekek soha nem kerültek valódi kapcsolatba egymással.

A kutatás vizsgálta a családjaik hatását a cigány gyerekek iskoláztatására. Részletesen elemzi a családon belüli konfliktusokat, amelyeket a társadalmi és kulturális környezet változása okoz, a kisebbség rasszizmusát, és az zárt cigány közösségböl való kikerüléssel járó nehézségeket. Az 1990-es években, a gazdasági visszaesés és a korábbi struktúrák müködésképtelensége miatt a cigányok megpróbáltak új stratégiákat kidolgozni, amelyeket a következőképp csoportosít a szerzö:

1. „passing” - asszimiláció a többségi csoporttal. Ennek legtipikusabb formája a többséghez tartozókkal kötött vegyes házasság;

2. cigány egyesületek létrehozása: a többségi társadalom szervezeteivel való együttműködésre koncentrálva, főként a lakhatás, iskoláztatás és szociális ellátások terén. Ezek az egyesületek, nagyon kevés kivételtől eltekintve nem tudtak megbirkózni vállalt feladataikkal;

3. elörejutás a tanulás révén;

4. a reménytelenség stratégiája: menekülés a kábítószerekhez.

A családokhoz kapcsolódó hármas stratégiát befolyásoló változók közül a legjelentősebbek:

a) A családszervezet típusa szerinti különbségek: a szilárd belső szerkezetü, nukleáris családokban élő gyerekek érték el a legtöbb iskolai sikert.

b) A lakóhely típusa szerinti változók: a letelepedett családok gyerekei sikeresebbek. A vándorló családok (pl. idénymunkából élők) esetében nagy gond a gyerekek iskoláztatása. 
c) Munkahely szerint: ahol legalább az egyik szülő rendelkezik állandó munkahellyel a gyerekek iskoláztatása rendszeresebb és sikeresebb.

d) A szülök iskolázottsága szerint: az írni-olvasni tudó, illetve a nyolc osztályt elvégzett szülők inkább segítik gyerekeiket a tanulásban.

e) A vallási és társadalmi szervezetekben való részvétel szerint: mindkét csoporthoz tartozás egyértelmủ motivációt jelent az írás-olvasás elsajátítására és a jobb iskolai teljesítményre.

A szerző hangsúlyozza, hogy mindezek mellett nagyon erös elbizonytalanító hatású lehet a szülői ház és az iskola egymástól eltérő üzenetei miatti diszharmónia, illetve a kettős kötésü üzenetek. A kettős kötésű helyzetekben a gyerek életében jelentős szerepet betöltő személy ellentmondásos üzenetet juttat el hozzá, egy üzeneten belül több, következetlen, gyakran egyenlötlen kommunikációs szint van, így a gyerek nem tudja értelmezni az üzenetet. (Például a tanár egy pozitív verbális üzenetét (dicséret) érvénytelenítheti a metakommunikációja (bizalmatlan pillantás, gesztus, irónia), de ilyen a szegregált osztályok puszta léte is, hiszen minek is tanulni egy eleve kudarcra ítélt csoport tagjaként.)

A kutatás színhelye a spanyol Aranda del Dueró város volt, amelynek jelenleg 30.000 lakosa van. A kisváros világának alapos tanulmányozása azonban kétségtelenül univerzális jelenségek rendszerét tárta fel, amely a hazai oktatásban dolgozók számára is releváns, nagyon értékes információkat tartalmaz. A szerző bevallott érzelmi kötődése a témához pedig élvezetessé és személyessé teszi a kötet olvasását.

José Eugenio Abajo Alcade: Cigány gyerekek az iskolában. Nyitott Könyvmühely, Budapest, 2008, 320 oldal 